Tips om medisinsk litteratur, andre bøker, filmer og elektroniske medier som bør anmeldes, sendes tidsskriftet@legeforeningen.no

\section{Å være ung tæringspasient}

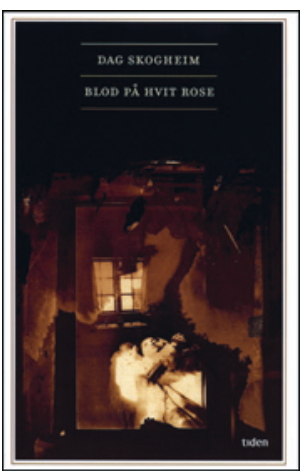

Dag Skogheim

Blod på hvit rose

141 s. Oslo: Tiden Norsk Forlag, 2012.

Pris NOK 349

ISBN 978-82-10-05199-9

Siden Dag Skogheim (f. 1928) debuterte med en lyrikksamling i 1970, har han stått bak mange bokutgivelser. Tuberkulose har vært et gjennomgangstema gjennom hele forfatterskapet. Bakgrunnen er hans egne erfaringer som pasient med lungetuberkulose, periodevis svært alvorlig, fra 1943 til 1954. Viktige ungdomsår ble preget av sykdom og sosial isolasjon.

I tuberkulosesykdommens historie er disse årene også viktige, fordi det var i denne perioden effektiv, medikamentell behandling ble tilgjengelig. Tuberkulosen mistet akkurat da mye av den makten den hadde hatt over befolkningen i tidligere generasjoner. Angsten for tæringen, den sosiale utstøtingen, sanatoriekultur på godt og vondt - dette ble etter hvert historie. Dag Skogheim opplevde overgangen.

Alle de sosiale stigmata som heftet ved tuberkulosen, gjorde at sykdommen ofte ble noe man nødig snakket om. Både fra bekjentskapskretsen og fra legekontoret vil mange kolleger ha lagt merke til at eldre pasienter som kanskje har tilbrakt år på sanatorium for lungetuberkulose, eller på et kysthospital for bein- og leddtuberkulose i ungdommen, nødig snakker om dette. Tuberkulose er tabu. Dag Skogheims bøker om den tidligere allestedsnærværende tuberkulosen er derfor viktige. De dokumenterer og forteller om en periode i norsk helse- og medisinhistorie som berørte mange, og som er ganske spesiell. Tross alvoret og de betydelige ringvirkningene tuberkulosen hadde, hadde den ellers forblitt fjern og kanskje glemt for sorgløs ungdom i dag.

Har Skogheim noe mer å skrive om denne gangen? Det er tuberkulosen sett fra en langt fra sorgløs ungdoms synsvinkel vi leser om i Blod på hvit rose. Det er om unggutten som plutselig blir tatt vekk fra verden og blir passiv pasient. Boken er personlig. Vi hører om frustrasjoner og forelskelser, avmakt og avgjørelser med langsiktige konsekvenser. Det er dette innenfra-ut-perspektivet som gjør Skogheims bok verd å lese, faktisk vel verd å lese, kanskje nettopp for ungdom.

\section{Øivind Larsen}

Institutt for helse og samfunn

Universitetet i Oslo

\section{Muligheter og fallgruver i epilepsibehandling}

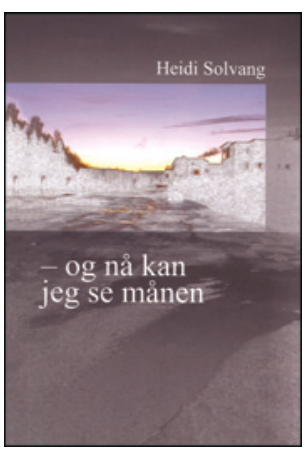

\author{
Heidi Solvang \\ Og nå kan jeg se månen
}

160 s. Oslo: Heidi Solvang, 2012. Pris NOK 150

ISBN 978-82-303-2063-1

Forfatteren ønsker å vise hvordan det er å leve med epilepsi og hvordan det oppleves å gjennomgå utredning for epilepsikirurgi med påfølgende rekonvalesens. Målgruppen er mennesker med epilepsi og deres familier, og helsepersonell som arbeider med denne pasientgruppen.

Hun gjengir sin egen sykehistorie i detalj og fletter inn tanker og følelser om opplevde tap og uoppfylte forventninger. Epilepsibehandling «på sitt beste og sitt verste» blir omtalt - dessverre handler det mest om det verste. Pennen flyter lett, kanskje litt for lett med både gjentakelser, uklarheter og en del små trykkfeil uten at lesbarheten svekkes vesentlig.

Det er en personlig bok - kanskje for personlig til å ha bred allmen interesse. Hun «kommer videre ved å snakke om ting». Det dreier seg ikke om noe standard pasientforløp. Forfatteren er en ressurssterk kvinne fra Oslo-området med evne til refleksjon, og hun har bred erfaring med utviklingen innen epilepsiomsorgen gjennom 47 år. Hun har fått alle mulige former for behandling, inklusive kirurgisk behandling ved et spesialsykehus i USA, vagusstimulator og modifisert Atkins diett. Dessverre har hun gang på gang opplevd bivirkninger og skuffelser, ingen behandling har ført til anfallsfrihet. Det gis ros og ris til ulike personer som hun har møtt i helsevesenet. Mange av dem vil nok være lette å identifisere for dem som kjenner miljøet. Hun etterlyser mer innlevelse. Man kan tenke seg at opplevelsene delvis har sin årsak i håp som helsevesenet ikke har kunnet innfri.

Utilstrekkelig og tilfeldig informasjonsarbeid til pasienten går som en rød trå gjennom boken. Hun opplever at «det hele mennesket» glemmes. Her har vi mye å lære av henne. Langtrukken utredning av epilepsikirurgi over mer enn fire år med lange ventetider mellom hver undersøkelse og vedvarende usikkerhet og manglende forutsigbarhet setter nok spor. Hun peker på mange ting som fagmiljøet burde trekke konsekvenser av, bl.a. i prosessen som spenner fra kampen mot epilepsi til kampen for å leve med epilepsi på best mulig måte.

Hun forteller sin historie slik hun har erfart den. §̊ lytte til en pasient er aldri bortkastet. Jeg har lest boken med utbytte. Den egner seg imidlertid i mindre grad som informasjon til andre pasienter pga. en del uklarheter og noen medisinske faktafeil, i tillegg til spesielle uheldige omstendigheter og negative karakteristikker. Den bør leses av personer i helsevesenet som jobber med epilepsipasienter, og den kan også være til ettertanke for andre som har kontakt med mennesker med kroniske sykdommer, bl.a. ansatte i Nav.

Eylert Brodtkorb

Avdeling for nevrologi og klinisk nevrofysiologi

St. Olavs hospital 